\title{
Complete root coverage in the treatment of Miller class III or RT2 gingival recessions: a systematic review and meta-analysis
}

\author{
Aitziber Fernández-Jiménez ${ }^{1}$, Ana-María García-De-La-Fuente ${ }^{1 *}$ (), Ruth Estefanía-Fresco ${ }^{1}$, \\ Xabier Marichalar-Mendia ${ }^{2}$, José-Manuel Aguirre-Urizar ${ }^{1}$ and Luis-Antonio Aguirre-Zorzano ${ }^{1}$
}

\begin{abstract}
Background: The primary objective of this systematic review and meta-analysis was to assess the evidence on complete root coverage (CRC) achieved by periodontal plastic techniques in the treatment of Miller class III/RT2 gingival recessions, comparing techniques developed along the twentieth century (pre-twenty-first) versus surgical approaches of the twenty-first century (21st).

Methods: An electronic bibliographic search was carried out in four databases up to December 2019, focusing on studies that reported CRC results in Miller class III or RT2 recessions treatment with at least a six-month follow-up. In addition, a random-effects models' meta-analysis was performed for the CRC, comparing pre-twenty-first versus twenty-first century techniques at 6 months, 12 months and more than 12 months.

Results: Thirty-seven publications were included. A total of 933 gingival recessions were treated, 298 with pretwenty-first century surgical techniques and 635 with techniques from the twenty-first century. CRC was achieved at 6 months on half of the recessions (pre-twenty-first: $57.60 \%$ vs. 21 st: $51.11 \%$ ), but decreased markedly for twenty-first century techniques at 12 months (pre-twenty-first: $63.82 \%$ vs. 21st: $32.87 \%$ ). Thereafter, this difference was the other way around (> 12 months: pre-twenty-first: 5.26\% vs. 21 st: 19.65\%). The meta-analysis showed a high heterogeneity, with no significant differences amongst the techniques.
\end{abstract}

Conclusions: Although CRC might be achievable by treating Miller class III or RT2 recessions with any of the described techniques, its long-term stability is not predictable. More randomized clinical trials with longer follow-ups and several visits, are needed. In addition, the patient's satisfaction should also be assessed.

Keywords: Class III gingival recession, RT2 gingival recession, Plastic surgery, Treatment outcome

\section{Introduction}

Periodontitis is a very prevalent pathology that ultimately leads to tooth loss in adult population [1-3]. As it progresses, multiple signs and symptoms may appear, including gingival recessions as a consequence of periodontal

\footnotetext{
*Correspondence: anamaria.garciad@ehu.eus

${ }^{1}$ Department of Stomatology II, University of the Basque Country (UPV/ EHU), UPV/EHU. Barrio Sarriena S/N, 48940 Leioa, Biscay, Spain

Full list of author information is available at the end of the article
}

attachment loss. Most of the recessions in periodontal patients involve the destruction of interproximal periodontal tissues, therefore, they could be classified as Miller class III [4] or RT2 [5] gingival recessions (GRs).

Miller classification [4] has been the most commonly used for identifying the type of recession and for predicting the results of its treatment in terms of root coverage (RC). Nevertheless, with the development of new treatment options, this classification no longer matches the treatment outcomes expected to be achieved [6, 7]. In an 
attempt to overcome this limitation, a new classification based on the interdental clinical attachment level was proposed [5] which has been accepted by the American Academy of Periodontology [8] and the European Federation of Periodontology [9].

In order to treat these challenging Miller class III [4] or RT2 [5] recessions, several mucogingival approaches have been proposed such as tunnel techniques, coronally advanced flaps, free gingival grafts, rotated techniques and two-stage procedures. These techniques have been developed along the twentieth century (pre-twenty-first century techniques) and the twenty-first century as well. Although modern modifications of classical techniques have been proposed in this century, aiming to increase the blood supply in the recipient area, there is no evidence about their predictability.

The main objective of these different treatment options is achieving complete root coverage (CRC), which has been accepted as the best indicator of success $[10,11]$. However, when considering the effectiveness of these techniques, it would be important to assess the percentage of RC [10] since a mean defect coverage of $80 \%-100 \%$ could also be a successful outcome [12].

Taking all this into account, a systematic review was carried out in order to collect the evidence about CRC outcomes achieved with techniques developed along twentieth century (pre-twenty-first century) versus more current surgical approaches (twenty-first century) used for the treatment of Class III [4] or RT2 [5] recessions.

\section{Methods}

\section{Review design and registration}

This systematic review was carried out following the Preferred Reporting Items for Systematic Review and Meta-Analysis (PRISMA) guidelines [13]. The protocol has previously been registered in the International Prospective Register of Ongoing Systematic Reviews (PROSPERO) in 2018 [CRD42018103599 Available from: http:// www.crd.york.ac.uk/PROSPERO/display_record.php? $\mathrm{ID}=\mathrm{CRD} 42018103599]$.

\section{Review question and search strategy}

The focused PICO question was: In patients with Class III [4] or RT2 [5] gingival recessions (population), what percentage of CRC (primary outcome) can we expect when using older (pre-twenty-first century) versus more modern (twenty-first century) mucogingival techniques?

A bibliographic search was performed in December 2019, in the National Library of Medicine (MEDLINE via PubMed), Web of Science, Cochrane Library and Scopus databases. The search strategy included the combination of the following keywords: "Class III recession", "RT2 recession" and "treatment": ((Class III recession) OR (RT2 recession)) AND (treatment).

It has been postulated that a follow-up of at least 6 months might be necessary in order to predict longterm outcomes of these procedures [14, 15], so only clinical studies with a follow-up at least of 6 months were included in this systematic review.

\section{Eligibility criteria}

Articles were included in this systematic review if they met the following inclusion criteria: (1) clinical studies including randomized clinical trials, cohort studies, retrospective studies, cases series and case reports in humans; (2) treatment of Miller class III or RT2 GRs around teeth (3) CRC was reported or could be obtained from the results provided; (4) that the results reported had at least six-month follow-up; (5) studies written in English and Spanish.

Instead, articles were to be excluded if: (1) they treated Miller class III or RT2 GRs, but there was no information about CRC or it was not possible to obtain this parameter; (2) letters and abstracts of meetings; (3) the resolution of the GR was not due to mucogingival treatment.

\section{Data extraction and quality of studies}

Screening of eligible studies, data extraction and risk of bias assessment (Grading of Recommendations. Assessment, Development and Evaluation (GRADE) system) [16] were performed independently by two different examiners (AFJ and AMGF), using the same inclusion and exclusion criteria. A third researcher (REF) was consulted in case of disagreements.

The year 2001 was taken as a reference point to divide the two study-groups. Pre-twenty-first century techniques included all surgical approaches (tunnel techniques, coronally advanced flaps, free gingival grafts, rotated techniques and two-stage procedures) developed between 1902 and 2000, and those developed from $1 / 01 / 2001$ until now were considered as twenty-first century techniques.

The quality of each type of study was assessed individually (in each included study) and globally (calculating percentages of all included studies) using risk of bias tables (GRADE system) [16]. In these tables, the following six parameters were recorded: random sequence generation, allocation concealment, blinding of participants and personnel, lack of incomplete outcome data, lack of selective reporting and being free of source of funding.

\section{Strategy for data synthesis}

The main objective was to assess the percentage of CRC (treatment success) obtained in the treatment of Miller class III [4]/RT2 [5] recessions comparing the 
mucogingival techniques described before twentyfirst century (pre-twenty-first century) versus the more recently described or modified techniques (twenty-first century). In the studies in which other types of recessions were treated in addition to Miller class III [4] or RT2 [5] GRs, only the data corresponding to these types of recessions were collected.

Likewise, mean baseline gingival recession depth as well as changes in other parameters, such as probing depth (PD), clinical attachment level (CAL) and keratinized tissue width (KTW) were recorded in millimeters.

For all the meta-analysis conducted, a random-effects model analysis was used. Heterogeneity was evaluated with Cochran's Q test and I2 statistic. The principal parameter was the percentage of CRC, which was used for consistency measurements comparing pre-twentyfirst century versus twenty-first century techniques in each follow-up, at 6 months, 12 months and more than 12 months. In addition, a cumulative meta-analysis for each follow-up time was performed, regardless of the technique used, in order to observe if there was any trend over time. Statistical significance was set at $\mathrm{p}<0.05$.

\section{Results}

Study selection

The PRISMA flow chart in Fig. 1 summarizes the retrieval process of the studies included in this systematic

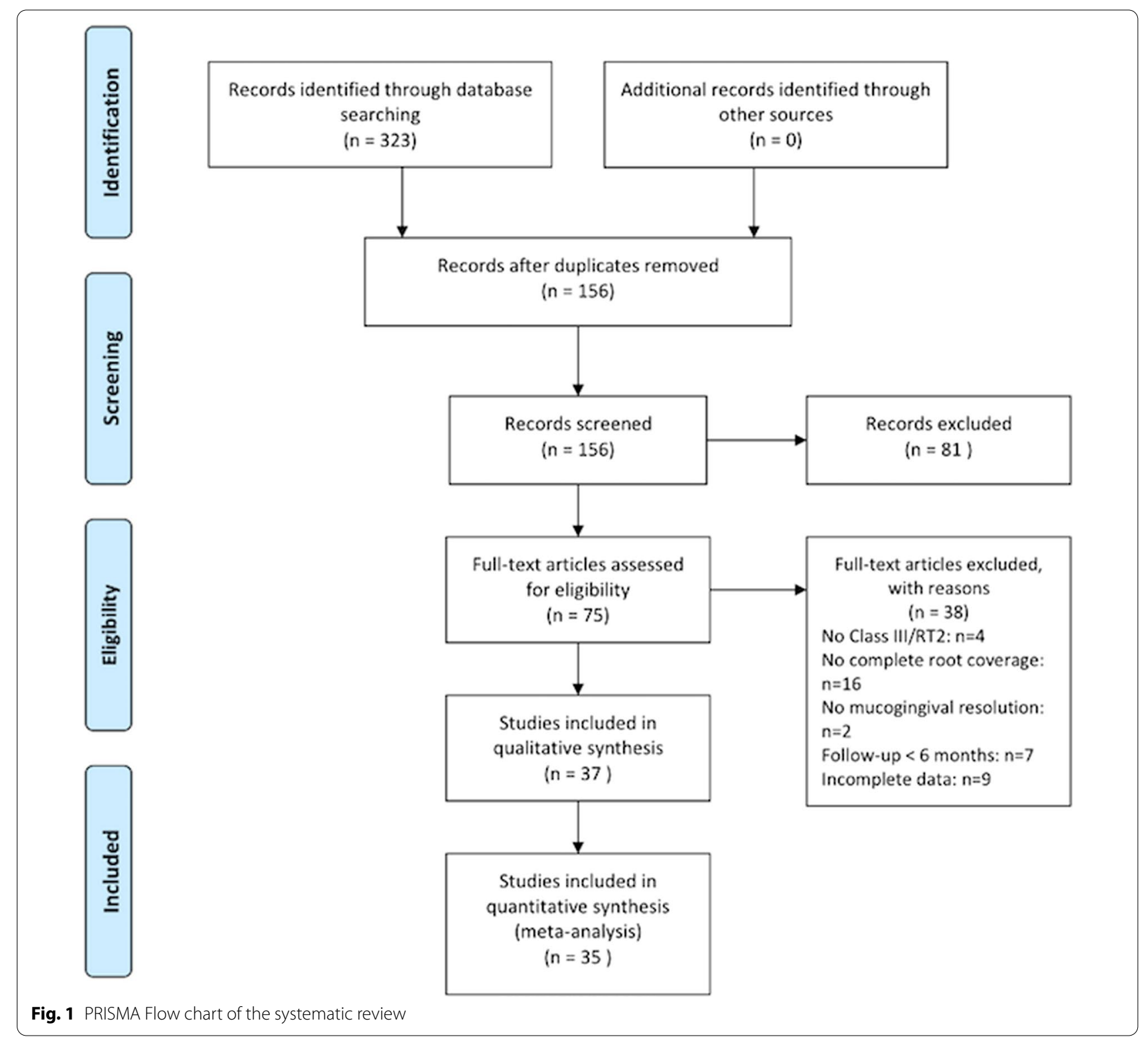


review. A total of 323 studies were found, 134 in PubMed database, 143 in Web of Knowledge, 28 in The Cochrane Library and 18 in Scopus.

After excluding duplicates, 156 studies were screened. The titles and the abstracts of all reports identified were read separately by the two authors (AFJ and AMGF) to include the articles where Miller class III [4]/RT2 [5] were treated with periodontal plastic surgical procedures; the inter-examiner global agreement was of $95.68 \%$ $($ Kappa $=0.91)$. Articles with no sufficient information in their title or abstract to discard them were also included. Finally, 75 full-text articles were assessed for eligibility. Thirty-eight studies were excluded (Fig. 1) with a global agreement of $94.12 \%$. Excluded studies and reasons for their exclusion are summarized on Additional file 1 (see Additional file 1).

Regarding the surgical techniques of GRs included in this systematic review, a total of 27 different surgical techniques were identified that were divided in two study groups: pre-twenty-first century [17-27] versus twentyfirst century [6, 28-42] techniques (Table 1).

\section{Study design and study population}

Seventeen studies were cases series [39-41, 43-56], nine were case reports $[31,35,38,57-62]$, seven were clinical trials $[6,7,14,42,63-65]$, and four were retrospective studies [36, 66-68]. Out of these 37 studies, only two studies $[7,65]$ used the classification proposed by Cairo et al. [5]. Almost half of the studies $(\mathrm{n}=16)$ included only Miller class III [4] or RT2 [5] recessions while, in the rest $(\mathrm{n}=18)$ Miller class I/II [4] or RT1 [5] or Miller class IV [4] $(n=1)$ recessions were also treated (Table 2).

Of the 16 articles focusing only on Miller class III GRs, nine of them $[7,31,35,38,39,57,61,62,64]$ treated single GRs, six studies $[6,53,56,58-60]$ included multiple GRs, and one study [67] included single or multiple Miller class III GRs. In the rest of articles, different kind of GRs were treated: single Miller class I, II and III GRs were treated in nine studies $[40,41,44,48,50,51,63,65$, 66], whereas multiple Miller class I, II, III and IV GRs were treated in five articles $[45,46,52,54,68]$, and single and multiple Miller class I, II and III GRs were treated in other seven articles [14, 42, 43, 46, 47, 49, 55] (Table 2).

Table 1 Periodontal plastic surgical techniques used in Class III or RT2 recessions treatment

\begin{tabular}{|c|c|}
\hline Pre-twenty-first century & twenty-first century \\
\hline \multicolumn{2}{|l|}{ Tunnel Technique (TT) } \\
\hline & Allen [34] \\
\hline & Aroca et al. [6] (MCAT) \\
\hline & Chao [36] (PST) \\
\hline & Ribeiro et al. [31] \\
\hline & Sculean and Allen [41](LCT) \\
\hline & Tözüm and Dini [29] \\
\hline & Zadeh [37] (VISTA) \\
\hline \multicolumn{2}{|l|}{ Coronally advanced flap (CAF) } \\
\hline Allen [23] & Zucchelli et al. [33](MCAF) \\
\hline Allen and Miller [24] & Mercado et al. [42] \\
\hline \multicolumn{2}{|l|}{ Ito et al. (PCTG) [26] } \\
\hline \multicolumn{2}{|l|}{ Langer and Langer [20] } \\
\hline \multicolumn{2}{|l|}{ Marggraf (BFP) [21] } \\
\hline \multicolumn{2}{|l|}{ Zucchelli and De Sanctis [27] } \\
\hline \multicolumn{2}{|l|}{ Free gingival graft (FGG) } \\
\hline Holbrook and Ochsenbein [19] & Allen and Cohen [28] (GUT) \\
\hline \multicolumn{2}{|l|}{ Rotated Technique (ROT) } \\
\hline Grupe and Warren [17] (LPF) & Deliberador et al. [35] (LPF + TT) \\
\hline Harris [25] (DPG) & Chambrone and Chambrone [32] (MLPF) \\
\hline \multirow[t]{2}{*}{ Nelson [22] (DPG) } & Lee et al. [39] (MLPF) \\
\hline & Zucchelli et al. [30] (LMCAF) \\
\hline \multicolumn{2}{|l|}{ Two-stage procedures (2SP) } \\
\hline \multirow[t]{2}{*}{ Bernimoulin et al. [18] (FGG + CAF) } & Núñez et al. [40] (2SSA: Odontoplasty/TT: Allen) \\
\hline & Zucchelli and De Sanctis [38] (Modified 2SP: FGG + LMCAF) \\
\hline
\end{tabular}

MCAT: Modified coronally advanced tunnel; VISTA: Vestibular incision subperiosteal tunnel access; PST: Pinhole surgical technique; LCT: Laterally closed tunnel; BFP: Bridge flap procedure; PCTG: Periosteal connective tissue grafting; MCAF: Modified coronally advanced flap; GUT: Gingival unit transfer; DPG: Double pedicle graft; LMCAF: Laterally moved coronally advanced flap; MLPF: Modified laterally positioned flap; LPF: Laterally positioned flap; 2SSA: Two-Step Surgical Approach 
Table 2 Characteristics of studies included for the systematic review and meta-analysis

\begin{tabular}{|c|c|c|c|c|c|c|c|}
\hline \multirow{2}{*}{$\begin{array}{l}\text { Class III /RT2 } \\
\text { studies }(n=37)\end{array}$} & \multirow{2}{*}{$\begin{array}{l}\text { Study type } \\
\text { (Class) }\end{array}$} & \multirow{2}{*}{$\begin{array}{l}\text { N RC } \\
\text { Class III/ } \\
\text { RT2 }\end{array}$} & \multirow{2}{*}{ RC location } & \multirow{2}{*}{$\begin{array}{l}\text { Follow-up } \\
\text { (months) }\end{array}$} & \multicolumn{2}{|c|}{ Surgical recipient site } & \multirow[t]{2}{*}{ Graft type } \\
\hline & & & & & Technique & Author & \\
\hline \multicolumn{8}{|l|}{ Case report $(n=9)$} \\
\hline $\begin{array}{l}\text { Cizza and Migues } \\
\text { [57] }\end{array}$ & $\begin{array}{l}\text { III } \\
S\end{array}$ & 1 & $M \times 2.3$ & $6 / 12$ & DPG $\ddagger$ & Harris [25] & SCTG \\
\hline $\begin{array}{l}\text { Deliberador et al. } \\
\text { [35] }\end{array}$ & $\begin{array}{l}\text { III } \\
S\end{array}$ & 1 & Md 3.1 & 12 & $\mathrm{LPF}+\mathrm{TT}+$ & $\begin{array}{l}\text { Deliberador et al. } \\
\text { [35] }\end{array}$ & SCTG \\
\hline $\begin{array}{l}\text { Gajendran and } \\
\text { Parthasarathy } \\
\text { [58] }\end{array}$ & $\begin{array}{l}\text { III } \\
M\end{array}$ & 2 & Md 3.1, 4.1 & 12 & GUTt & $\begin{array}{l}\text { Allen and Cohen } \\
\text { [28] }\end{array}$ & FGG \\
\hline Luthra et al. [59] & $\begin{array}{l}\text { III } \\
M\end{array}$ & 2 & $M \times 2.3 / 2.4$ & $6 / 12$ & CAF $\neq$ & Allen [23] & $\begin{array}{l}\text { Periosteal pedicle } \\
\text { graft + Autog- } \\
\text { enous bone }\end{array}$ \\
\hline \multirow[t]{2}{*}{$\begin{array}{l}\text { Moussa and Bis- } \\
\text { sada [60] }\end{array}$} & $\begin{array}{l}\text { III } \\
M\end{array}$ & 6 & $M \times 1.5 / 1.3 / 1.2 / 1.1$ & 12 & TT† & Allen [34] & $\mathrm{ADM}$ \\
\hline & & & $M \times 2.4 / 2.6$ & & MCAF† & Zucchelli et al. [33] & SCTG \\
\hline Rath et al. [61] & $\begin{array}{l}\text { III } \\
S\end{array}$ & 1 & Md 4.1 & 6 & $2 \mathrm{SP}(\mathrm{FGG} / \mathrm{CAF}) \neq$ & $\begin{array}{l}\text { Bernimoulin et al. } \\
\text { [18] }\end{array}$ & FGG/BB $\left(\right.$ BioMed $\left.^{\circledR}\right)$ \\
\hline Rath et al. [62] & $\begin{array}{l}\text { III } \\
S\end{array}$ & 1 & Md 4.1 & 6 & FGG $\neq$ & $\begin{array}{l}\text { Holbrook and } \\
\text { Ochsenbein [19] }\end{array}$ & FGG \\
\hline Ribeiro et al. [31] & $\begin{array}{l}\text { III } \\
S\end{array}$ & 1 & $M \times 2.4$ & 36 & $\mathrm{TT}+$ & Ribeiro et al. [31] & SCTG \\
\hline $\begin{array}{l}\text { Zuchelli and De } \\
\text { Sanctis [38] }\end{array}$ & $\begin{array}{l}\text { III } \\
\mathrm{S}\end{array}$ & 1 & Md 3.6 & $12 / 60$ & $\begin{array}{l}\text { M2SP (FGG/ } \\
\text { LMCAF)† }\end{array}$ & $\begin{array}{l}\text { Zuchelli and De } \\
\text { Santics [38] }\end{array}$ & FGG/No \\
\hline \multicolumn{8}{|l|}{ Case series $(n=17)$} \\
\hline Boltchi et al. [43] & $\begin{array}{l}\text { I, II,III } \\
\text { Sor M }\end{array}$ & 14 & NR & 6 & CAF $\neq$ & Allen [23] & BB $\left(\right.$ Guidor $\left.^{\circledR}\right)$ \\
\hline Carnio et al. [44] & $\begin{array}{l}\|,\| 1 \| \\
S\end{array}$ & 2 & Mx/Md 1.3/2.3 & $6 / 12$ & DPG $\ddagger$ & Nelson [22] & SCTG \\
\hline Cosgarea et al. [45] & $\mathrm{M}_{\mathrm{M}}$ & 25 & $\begin{array}{l}\text { Mx/Md incisors, } \\
\text { canines or } \\
\text { premolars }\end{array}$ & 12 & MCAT† & Aroca et al. [6] & ADM (Mucoderm $\left.{ }^{\circledR}\right)$ \\
\hline Garg et al. [46] & I and III M & 9 & $\begin{array}{l}\text { Mx incisor, canines } \\
\text { and premolar }\end{array}$ & 6 & VISTA† & Zadeh [37] & $\mathrm{BB}(\mathrm{PRF}) / \mathrm{No}$ \\
\hline Gupta et al. [47] & $\begin{array}{l}\text { I, II,III } \\
\text { Sor M }\end{array}$ & 7 & Md incisors & 9 & $\mathrm{BFP} \neq$ & Marggraf [21] & No \\
\hline Jepsen et al. [48] & $\begin{array}{l}|,| I,|l| \\
S\end{array}$ & 8 & $\begin{array}{l}\text { Mx/Md 1.3/ 2.3/ } \\
\quad 3.3\end{array}$ & 12 & CAF $\neq$ & Allen [23] & BB (Atrisorb $\left.{ }^{\circledR}\right)$ \\
\hline \multicolumn{8}{|l|}{ Case series $(n=17)$} \\
\hline Lee et al. [39] & Only III S & 2 & Md 4.3 & $6 / 36$ & MLPF† & Lee et al. [39] & SCTG \\
\hline Nart et al. [49] & $\begin{array}{l}\text { II and III } \\
\text { Sor M }\end{array}$ & 7 & Md incisors & $11.70(6.21)$ & CAF $\neq$ & $\begin{array}{l}\text { Zucchelli and De } \\
\text { Sanctis [27] }\end{array}$ & SCTG \\
\hline $\begin{array}{l}\text { Nart and Valles } \\
\text { [50] }\end{array}$ & $\begin{array}{l}\| \text { and III } \\
S\end{array}$ & 7 & Md incisors & $20.53(8.89)$ & TT† & $\begin{array}{l}\text { Tözüm and Dini } \\
\text { [29] }\end{array}$ & SCTG \\
\hline Núñez et al. [40] & $\begin{array}{l}\| \text { and III } \\
S\end{array}$ & 7 & Md 3.1, 4.1 & 12 & $\begin{array}{l}\text { 2SSA (Odonto- } \\
\text { plasty/TT) }+\end{array}$ & Núñez et al. [40] & SCTG \\
\hline Pini Prato et al. [51] & $\begin{array}{l}\text { I and III, } \\
\mathrm{S}\end{array}$ & 25 & $\begin{array}{l}\text { Mx/Md incisors, } \\
\text { canines or } \\
\text { premolars }\end{array}$ & $12 / 240$ & CAF $\neq$ & $\begin{array}{l}\text { Allen and Miller } \\
\text { [24] }\end{array}$ & No \\
\hline $\begin{array}{l}\text { Romanos et al. } \\
\text { [52] }\end{array}$ & $\begin{array}{l}\mathrm{I}, \| \text { and III } \\
M\end{array}$ & 48 & $\mathrm{Mx} / \mathrm{Md}$ & 12 & MCAT† & Aroca et al. [6] & ADM (Alloderm ${ }^{\circledR}$ ) \\
\hline Sato et al. [53] & Only III M & 4 & Md central incisors & $12 / 24$ & PCTG $\neq$ & Ito et al. [26] & $\mathrm{SCTG}+\mathrm{EMD}$ \\
\hline Sculean et al. [54] & I, II and III M & 5 & $\mathrm{Mx}$ & 12 & MCAT† & Aroca et al. [6] & $\mathrm{SCTG}+\mathrm{EMD}$ \\
\hline Sculean et al. [55] & $\begin{array}{l}\text { I and III } \\
\text { Sor M }\end{array}$ & 7 & $M x$ & 12 & MCAT† & Aroca et al. [6] & SCTG \\
\hline $\begin{array}{l}\text { Sculean and Allen } \\
\text { [41] }\end{array}$ & I, II and III S & 10 & $\begin{array}{l}\text { Md incisors and } \\
\text { canines }\end{array}$ & 12 & LCT† & $\begin{array}{l}\text { Sculean and Allen } \\
\text { [41] }\end{array}$ & $\mathrm{SCTG}+\mathrm{EMD}$ \\
\hline
\end{tabular}


Table 2 (continued)

\begin{tabular}{|c|c|c|c|c|c|c|c|}
\hline \multirow{2}{*}{$\begin{array}{l}\text { Class III /RT2 } \\
\text { studies }(n=37)\end{array}$} & \multirow{2}{*}{$\begin{array}{l}\text { Study type } \\
\text { (Class) }\end{array}$} & \multirow{2}{*}{$\begin{array}{l}\text { N RC } \\
\text { Class III/ } \\
\text { RT2 }\end{array}$} & \multirow{2}{*}{ RC location } & \multirow{2}{*}{$\begin{array}{l}\text { Follow-up } \\
\text { (months) }\end{array}$} & \multicolumn{2}{|c|}{ Surgical recipient site } & \multirow[t]{2}{*}{ Graft type } \\
\hline & & & & & Technique & Author & \\
\hline Yaman et al. [56] & Only III M & 68 & $\mathrm{Mx} / \mathrm{Md}$ & 12 & MCAT† & Aroca et al. [6] & SCTG \\
\hline \multicolumn{8}{|c|}{ Clinical trials $(n=7)$} \\
\hline Aroca et al. [6] & Only III M & 139 & $\mathrm{Mx} / \mathrm{Md}$ & $6 / 12$ & MCAT† & Aroca et al. [6] & SCTG/ + or-EMD \\
\hline Cairo et al. [7] & Only RT2 S & 29 & $\begin{array}{l}\text { Mx incisors, } \\
\text { canines and } \\
\text { premolars }\end{array}$ & 6 & CAF $\neq$ & $\begin{array}{l}\text { Allen and Miller } \\
\text { [24] }\end{array}$ & SCTG/ No \\
\hline Cueva et al. [14] & I, II and III S or M & 7 & $\begin{array}{l}\text { Mx/Md incisors, } \\
\text { canines and } \\
\text { premolars }\end{array}$ & 6 & CAF $\neq$ & $\begin{array}{l}\text { Allen and Miller } \\
\text { [24] }\end{array}$ & EMD/No \\
\hline Mercado et al. [42] & III and IV M & 127 & $\begin{array}{l}\text { Md incisors and } \\
\text { canines }\end{array}$ & 36 & CAF† & Mercado et al. [42] & SCTG/ + or-EMD \\
\hline Ozcelik et al. [63] & I, II and III S & 30 & $\begin{array}{l}\text { Mx/Md incisors } \\
\text { and canines }\end{array}$ & 6 & MLPF† & $\begin{array}{l}\text { Chambrone and } \\
\text { Chambrone [32] }\end{array}$ & No \\
\hline Ozcelik et al. [65] & $\begin{array}{l}\text { RT1 and RT2 } \\
\text { S }\end{array}$ & 62 & $\begin{array}{l}\text { Mx/Md incisors } \\
\text { and canines }\end{array}$ & 6 & CAF $\neq$ & $\begin{array}{l}\text { Allen and Miller } \\
\text { [24] }\end{array}$ & SCTG \\
\hline Ucak et al. [64] & $\begin{array}{l}\text { Only III } \\
\text { S }\end{array}$ & 50 & $\begin{array}{l}\text { Mx/Md incisors } \\
\text { and canines }\end{array}$ & 6 & LMCAF† & Zucchelli et al. [30] & No \\
\hline \multicolumn{8}{|c|}{ Restrospective studies $(n=4)$} \\
\hline \multirow[t]{2}{*}{$\begin{array}{l}\text { César-Neto et al. } \\
\text { [66] }\end{array}$} & $\begin{array}{l}\| \text { and III } \\
\text { S }\end{array}$ & 3 & $\begin{array}{l}\text { Mx/Md incisors, } \\
\text { canines and } \\
\text { premolars }\end{array}$ & 6 & CAF $\neq$ & $\begin{array}{l}\text { Langer and Langer } \\
\text { [20] }\end{array}$ & SCTG \\
\hline & & 4 & & & DPG/LPF $\neq$ & $\begin{array}{l}\text { Harris [25]/Grupe } \\
\text { and Warren [17] }\end{array}$ & \\
\hline Chao [36] & I, II and III S or M & 36 & $\mathrm{Mx} / \mathrm{Md}$ & $15(5.2)$ & PST† & Chao $[36]$ & $\begin{array}{l}\left.\text { BB (Bio-Gide }{ }^{\circledR}\right) / \\
\text { ADM (Alloderm }{ }^{\circledR} \text { ) }\end{array}$ \\
\hline \multirow[t]{3}{*}{ Esteibar et al. [67] } & Only III, S or M & 121 & $\mathrm{Mx} / \mathrm{Md}$ & 12 & FGG $\neq$ & $\begin{array}{l}\text { Holbrook and } \\
\text { Ochsenbein [19] }\end{array}$ & FGG \\
\hline & & & & & CAF $\neq$ & $\begin{array}{l}\text { Langer and Langer } \\
\text { [20] }\end{array}$ & SCTG \\
\hline & & & & & DPG $\neq$ & Harris [25] & \\
\hline Gil et al. [68] & $\mathrm{I}, \mathrm{II}$ and III M & 54 & $\mathrm{Mx} / \mathrm{Md}$ & $\geq 12(14.6(4.6))$ & VISTA† & Zadeh [37] & $\begin{array}{l}\text { SCTG/ADM } \\
\left.\text { (Perioderm }^{\circledR}\right) / \\
\text { XCM }\left(\text { Muco- }^{\text {Muco- }}\right. \\
\left.\text { graft }^{\circledR}\right)+ \text { PDGF } \\
(\text { GEM215 }\end{array}$ \\
\hline
\end{tabular}

S: single; RC: Recession; M: multiple; Mx: Maxilla; Md: Mandible; NR: No reported; †: twenty-first century technique; ¥: pre-twenty-first century technique; GUT: Gingival unit transfer; CAF: Coronally avanced flap; FGG: Free gingival graft; TT: Tunnel technique; MCAF: Modified coronally advanced flap; 2SP: Two-stage procedures; 2SSA: Two-stage surgical approach; LMCAF: Laterally moved coronally advanced flap; DPG: Double pedicle graft; LPF: Laterally positioned flap; LCT: Laterally closed tunnel; VISTA: Vestibular incision subperiosteal tunnel access; MCAT: Modified coronally advanced tunnel; MLPF: Modified laterally positioned flap; BFP: Bridge flap procedure; PCTG: Periosteal connective tissue grafting; PST: Pinhole surgical technique; ADM: Acelullar dermal matrix; XCM: Xenogenic collagen matrix; SCTG: Subepithelial connective tissue graft; BB: Bioabsorbable barrier; EMD: Enamel matrix derivative; PRF: Platelet-rich fibrin; PDGF: Platelet derived growth factor

\section{Type of intervention}

In the treatment of Miller class III [4] or RT2 [5] recessions, the tunnel preparation and the CAFs were the most widely used surgical techniques. Regarding surgical procedures developed along twentieth century, they were used in 16 clinical studies [7, 14, 43, 44, 47-49, 51, 53, 57, 59, 61, 62, 65-67] (Table 2).

In the majority of the studies, a subepithelial connective tissue graft or free gingival graft was used, followed by other alternatives such as connective tissue substitutes (acellular dermal matrix, porcine acellular dermal matrix)
[36, 45, 52, 60, 68], bioabsorbable membranes (collagen membranes, PRF membranes) [36, 43, 46, 48], plateletderived growth factors $\left(\right.$ GEM $\left.21 S^{\circledR}\right)$ [68] and enamel matrix proteins $\left(\right.$ Emdogain $\left.^{\circledR}\right)[6,14,42]$. In 3 studies [47, $51,63]$ no grafts were used (Table 2 ).

\section{Risk of bias assessment}

Current evidence, mainly based on case reports and cases series, presented a high risk of bias (Fig. 2). Nevertheless, 7 clinical trials provided a higher level of evidence (Fig. 3). 


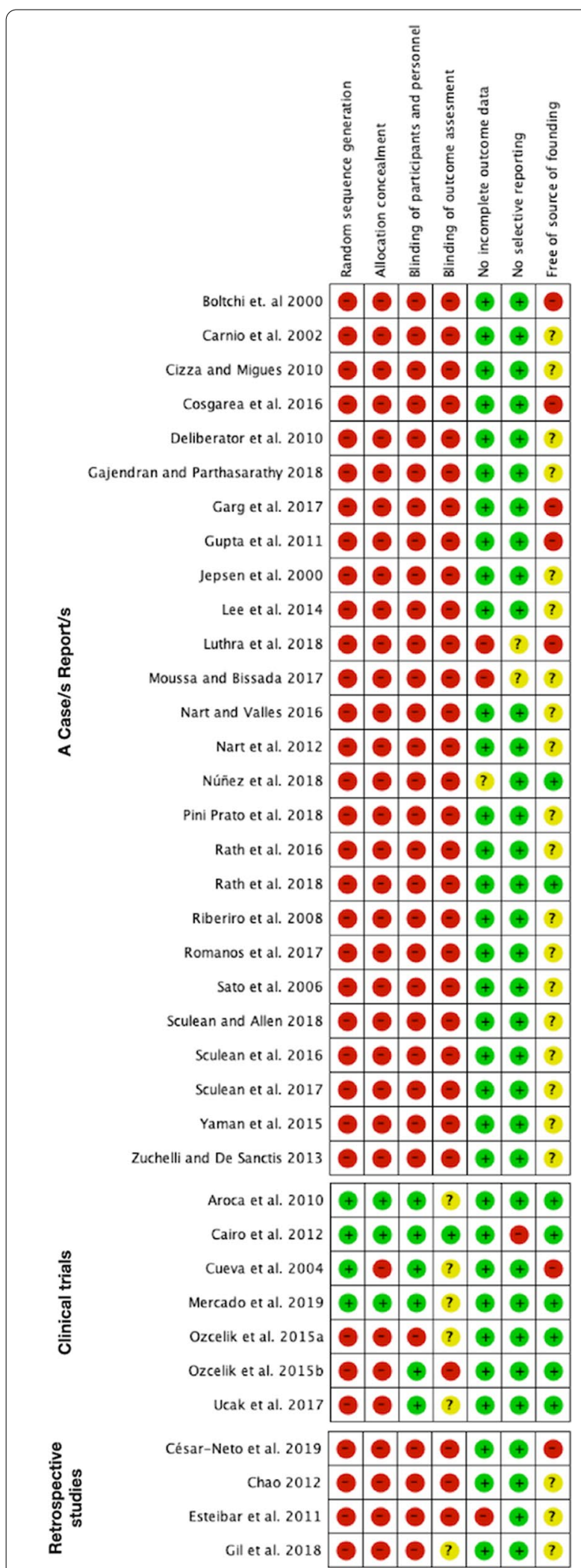

Fig. 2 Summary of the risk of bias, assessing each risk of bias item in each included study

\section{Synthesis of results}

To quantitatively address the focused question of this review, data from articles were extracted and organized into tables to condense an overview of intervention characteristics and clinical outcomes. Articles in the tables were organized according to the type of study, as well.

A total of 933 Miller class III [4] or RT2 [5] GRs from 37 studies were evaluated in the present systematic review. Of these lesions, 298 were treated with pretwenty-first century surgical techniques [17-27] and 635 GRs with techniques [6, 28-42] from the twentyfirst century. They were mainly single recessions involving incisors, canines and premolars of both jaws (Table 2).

Baseline measurements of the RC, PD and KTW, as well as the number of recessions that showed CRC and the corresponding percentage of the total, are shown in Table 3. There were no clinical differences (mean $<1 \mathrm{~mm}$ ) between the two treatment groups in baseline measurements of recession, PD and KTW. Although most studies had followed-up these recessions up to 6 and 12 months, only one clinical trial [42] and two cases studies $[38,51]$ reported results in advance, at three, five and twenty years, respectively.

\section{Complete root coverage}

Regardless of the technique used in the treatment of Miller class III [4] or RT2 [5] recessions, CRC percentage of $54.88 \%(n=118 / 215$ GRs $), 42.07 \%(n=215 / 511$ GRs) and $18.23 \%(n=35 / 192$ GRs $)$ was reported in the 6-, 12- and more than 12-months follow-up points, respectively (Table 3 ).

Hence, breaking down this variable according to the technique used, a CRC percentage of $57.60 \%$ $(\mathrm{n}=72 / 125$ GRs $)$ and $51.11 \%(\mathrm{n}=46 / 90$ GRs $)$ was observed at six months of $63.82 \%,(n=97 / 152 \mathrm{GRs})$ and $32.87 \%(\mathrm{n}=118 / 359 \mathrm{GRs})$ at 12 months and decreasing beyond 12 months, to a $5.26 \%(n=1 / 19$ recessions) and $19.65 \%(\mathrm{n}=34 / 173 \mathrm{GRs})$, for the pre-twenty-first and twenty-first century treatment techniques, respectively.

\section{Periodontal parameters (PD, CAL, KTW)}

Changes in some of the clinical parameters (PD, CAL, and KTW) were reported in 25 studies (Table 3). Regarding PD, an average reduction of less than $1 \mathrm{~mm}$ was observed in both groups, in the three time-points (six, 12 and beyond 12 months).

In relation to the CAL, at six-month follow-up, a higher gain was observed for the pre-twenty-first century treatment group (pre-twenty-first: $4.61 \mathrm{~mm}$ vs. 21st: $2.72 \mathrm{~mm}$ ). However, the opposite was seen in the 


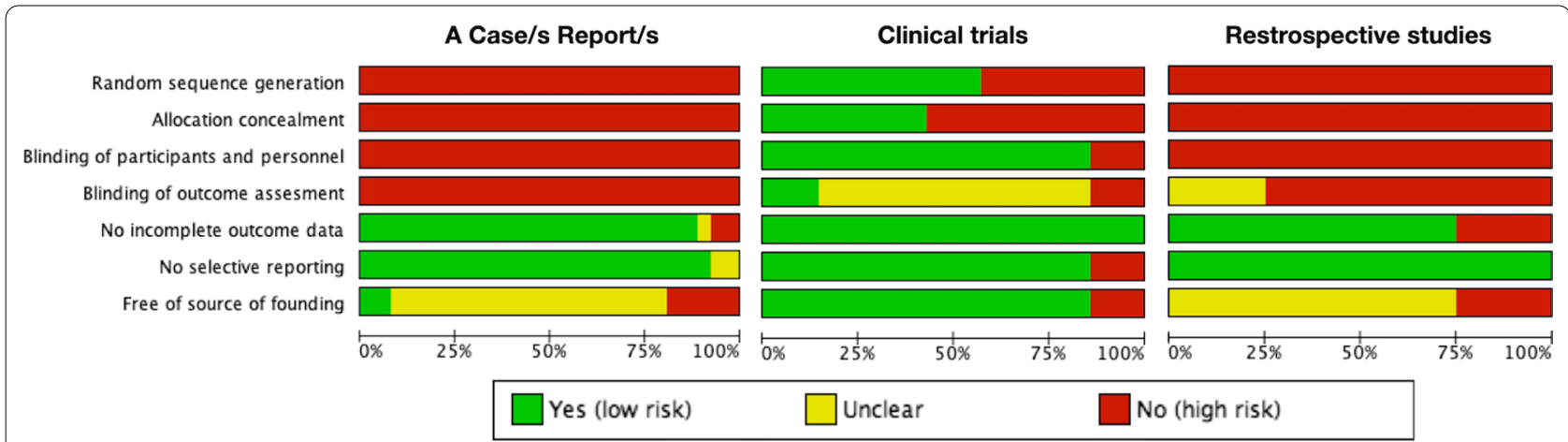

Fig. 3 Graph of the risk of bias, presenting each risk of bias item as a percentage across all the included studies

12-month (pre-twenty-first: $3.61 \mathrm{~mm}$ vs. $21 \mathrm{st}: 4.38 \mathrm{~mm}$ ) and in the beyond 12-month (pre-twenty-first: $1.72 \mathrm{~mm}$ vs. 21st: $4.40 \mathrm{~mm}$ ) evaluations.

Finally, concerning the KTW, a significant gain could be observed for both treatment groups at six-month follow-up (pre-twenty-first: $4.35 \mathrm{~mm}$ vs. $21 \mathrm{st}: 2.93 \mathrm{~mm}$ ), which was reduced at the 12-month assessment (pretwenty-first: $2.37 \mathrm{~mm}$ vs. $21 \mathrm{st}: 1.79 \mathrm{~mm}$ ). However, after 12 months of follow-up, the gain in the KTW seemed to remain stable around $2 \mathrm{~mm}$ in both groups (pre-twentyfirst: $1.49 \mathrm{~mm}$ vs. $21 \mathrm{st}$ : $2.48 \mathrm{~mm}$ ). Pini-Prato et al. [51] observed a reduction in the KTW from 12 months on (12 months: $-0.32 \mathrm{~mm} / 240$ months: $-0.77 \mathrm{~mm}$ ).

\section{Meta-analysis}

Although a total of 37 studies were included for the qualitative analysis, two of them $[6,47]$ were excluded for the meta-analysis because did not meet the inclusion criteria. Whereas, Aroca et al. [6] provided the results of CRC at the level of the intervened subjects, Gupta et al. [47] informed of the obtained coverage at 9 months which was a time-point not included in the pre-established analysis groups. The meta-analysis (Fig. 4) showed a high heterogeneity between studies which prevented obtaining significance when comparing pre-twenty-first century techniques versus twenty-first century techniques. Even so, a certain trend could be observed in the cumulative meta-analysis (Fig. 5), with the results of CRC tending to improve in the most current studies with a 12-month follow-up, whereas in those with a follow-up beyond 12 months, the opposite trend was seen.

\section{Discussion}

The present systematic review considered all types of studies which focused on Miller class III [4] or RT2 [5] GRs, due to the lack of evidence regarding the CRC of these challenging GRs. Until now, only nine [31, 36, $38,39,42,50,51,53,68]$ out of the 37 included studies showed a follow-up longer than 12 months, one of them being a randomized clinical trial [42]. Furthermore, only two studies $[38,51]$ had a long-term follow-up of five and twenty years, respectively.

It was decided to divide the surgical techniques using the twenty-first century as a threshold, because it is considered that, from that moment on, new techniques or modifications of the previous original techniques had been described, which were headed towards minimally invasive surgery, in an attempt to overcome the difficulties, the former presented.

Considering globally all the selected studies in this systematic review, CRC is possible, but the percentage of the CRC seems to decrease exponentially with a longer follow-up time (six months: 54.88\%; 12 months: 42.07\% and $>12$ months: $18.23 \%$ ). In this way, the study by PiniPrato et al. [51] which had the longest follow-up, was the one showing no stability of the CRC in the 17 recessions after 20 years of follow-up. When considering both groups (pre-twenty-first century [17-27] and twenty-first century $[6,28-42]$ techniques) independently, both of them showed CRC in half of the treated recessions (pretwenty-first: $57.60 \%$ vs. 21 st: $51.11 \%$ ) at six months. The CRC decreased markedly for the twenty-first century [6, 28-42] techniques at 12 months (pre-twenty-first: $63.82 \%$ vs. 21 st: $32.87 \%)$. Nevertheless, beyond the 12-month follow-up, the tendency of the CRC was inverted (pretwenty-first: $5.26 \%$ vs. 21 st: $19.65 \%$ ). This could be due to the higher number of recessions treated with the more current techniques at 12 months (pre-twenty-first: $\mathrm{n}=152$ vs. 21 st: $\mathrm{n}=359$ ), and beyond 12 months (pretwenty-first: $n=19$ vs. 21 st: $n=173$ ). In fact, the number of recessions treated with the more modern techniques were more than the double at 12 months and more than nine times beyond 12 months; it might explain the large differences in CRC. In addition, other factors related to the defect, the patient and the surgical characteristics may have influenced the CRC obtained. 
Fernández-Jiménez et al. BMC Oral Health $\quad$ (2021) 21:145

Page 9 of 18

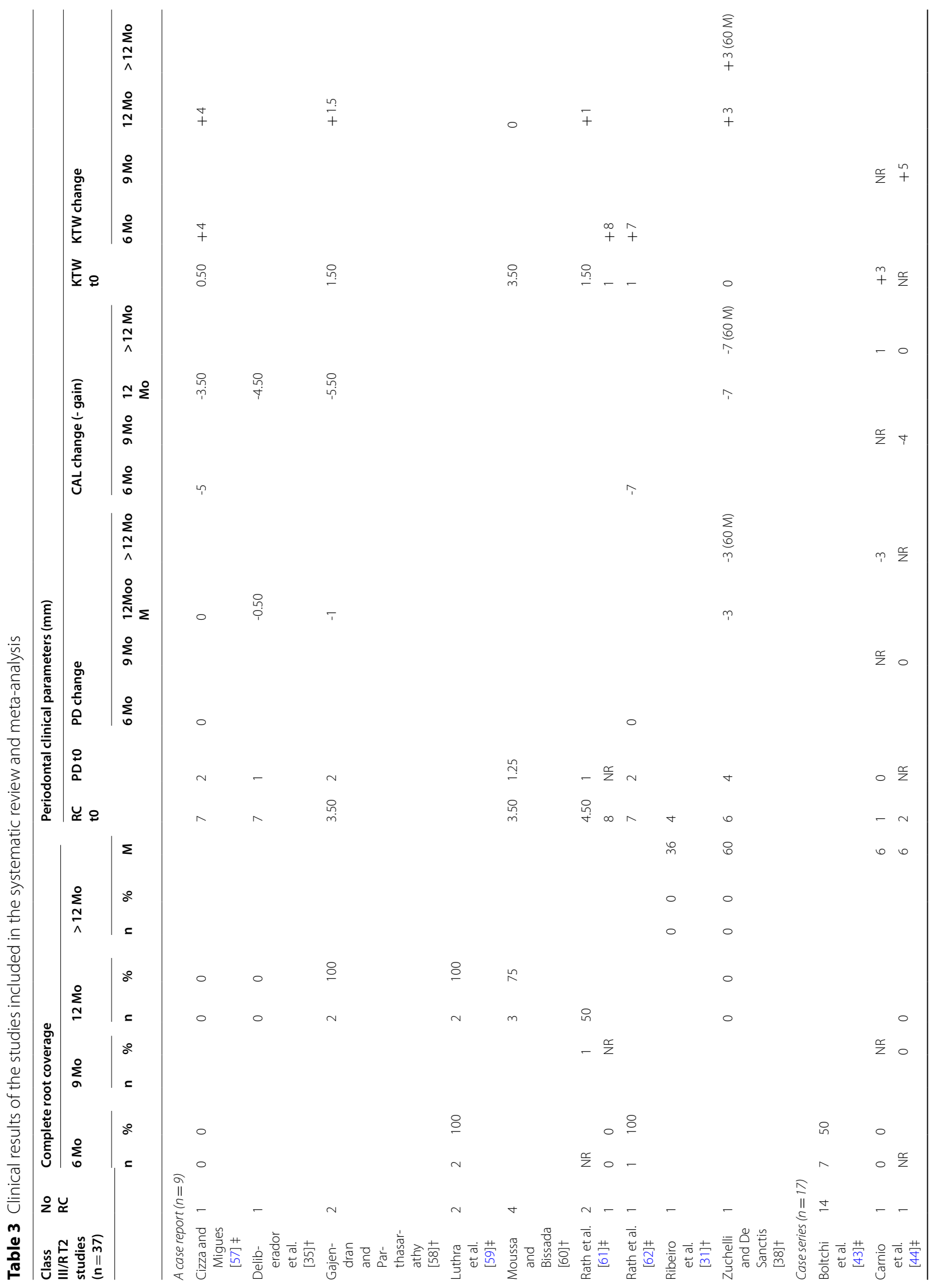




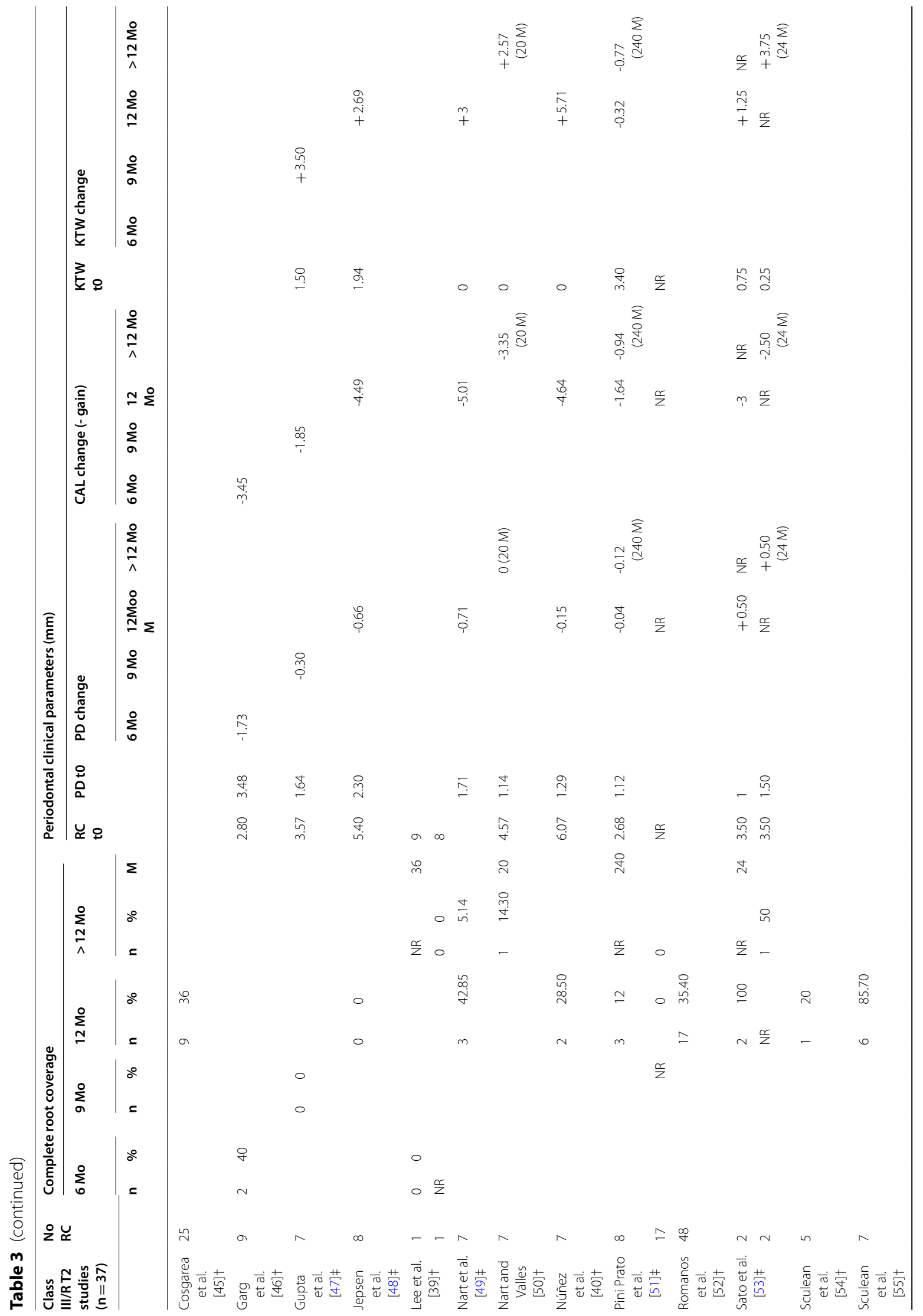




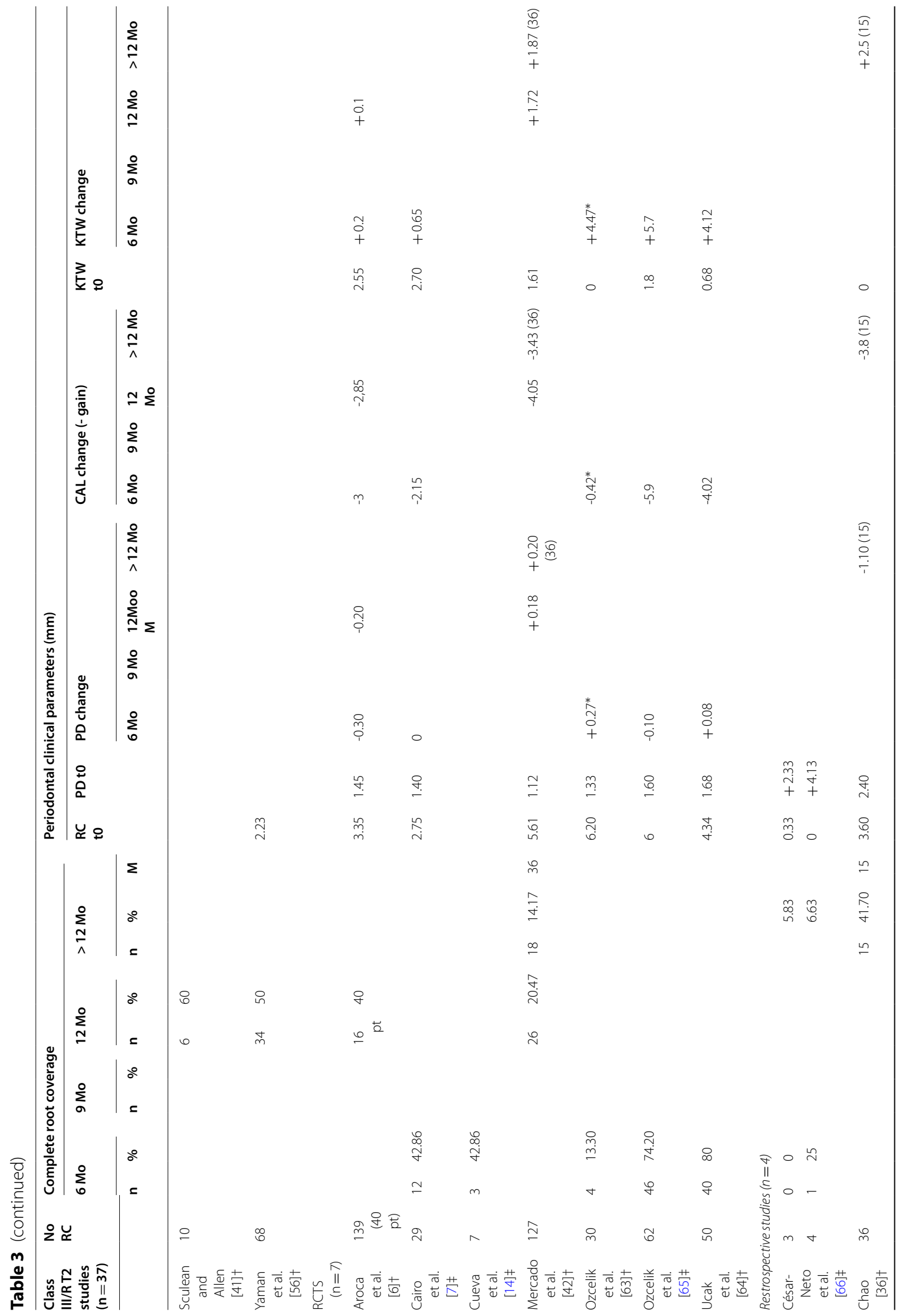




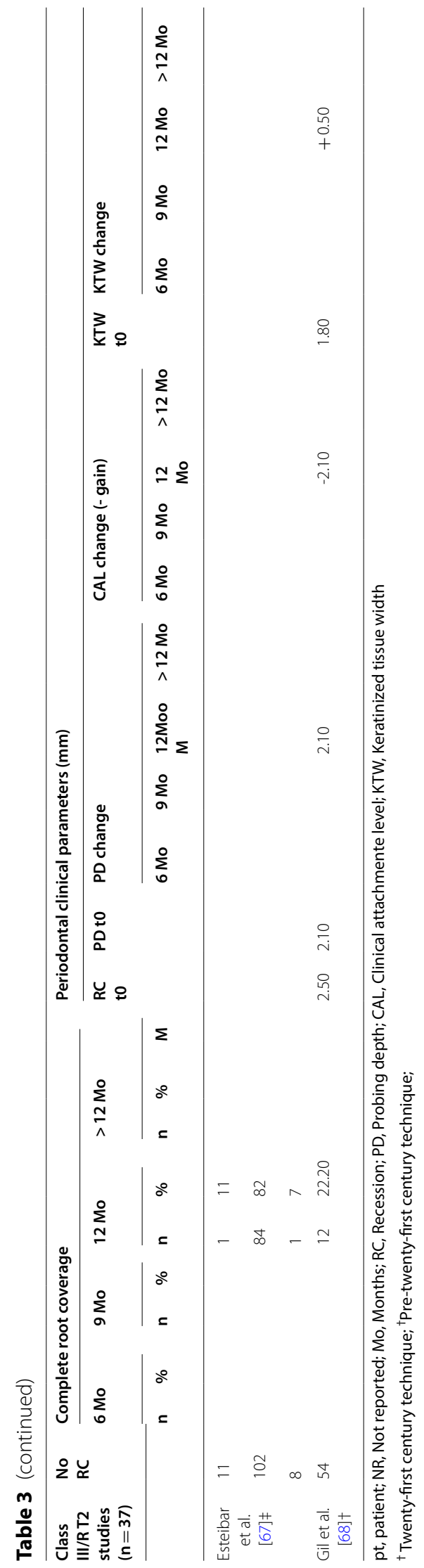




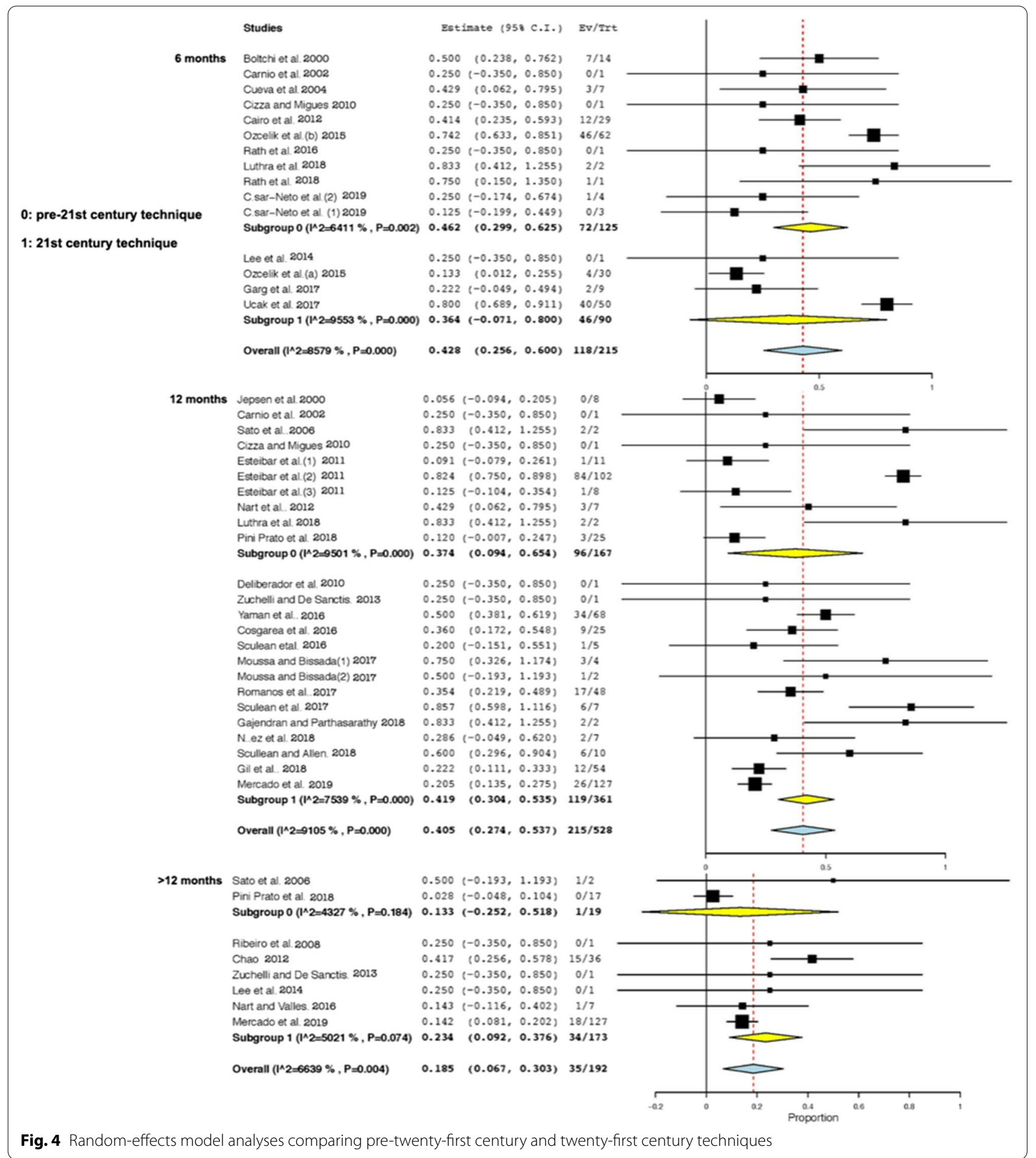

At recession level, there were other parameters that may have influenced the achievement of the desired CRC, such as interproximal soft tissue integrity $[67,69$, 70], avascular root surface areas (AERSA) [5, 63] size of the recession (baseline depth and width) [27, 56, 71], periodontal biotype [69], which directly influences the flap thickness [72] and, finally, tooth and location. Thus, it was more difficult to achieve CRC in GRs located in the mandible [73], as well as in molars and premolars $[74,75]$

It must be noted that an attempt was made to elucidate what baseline parameters may favor achieving CRC 


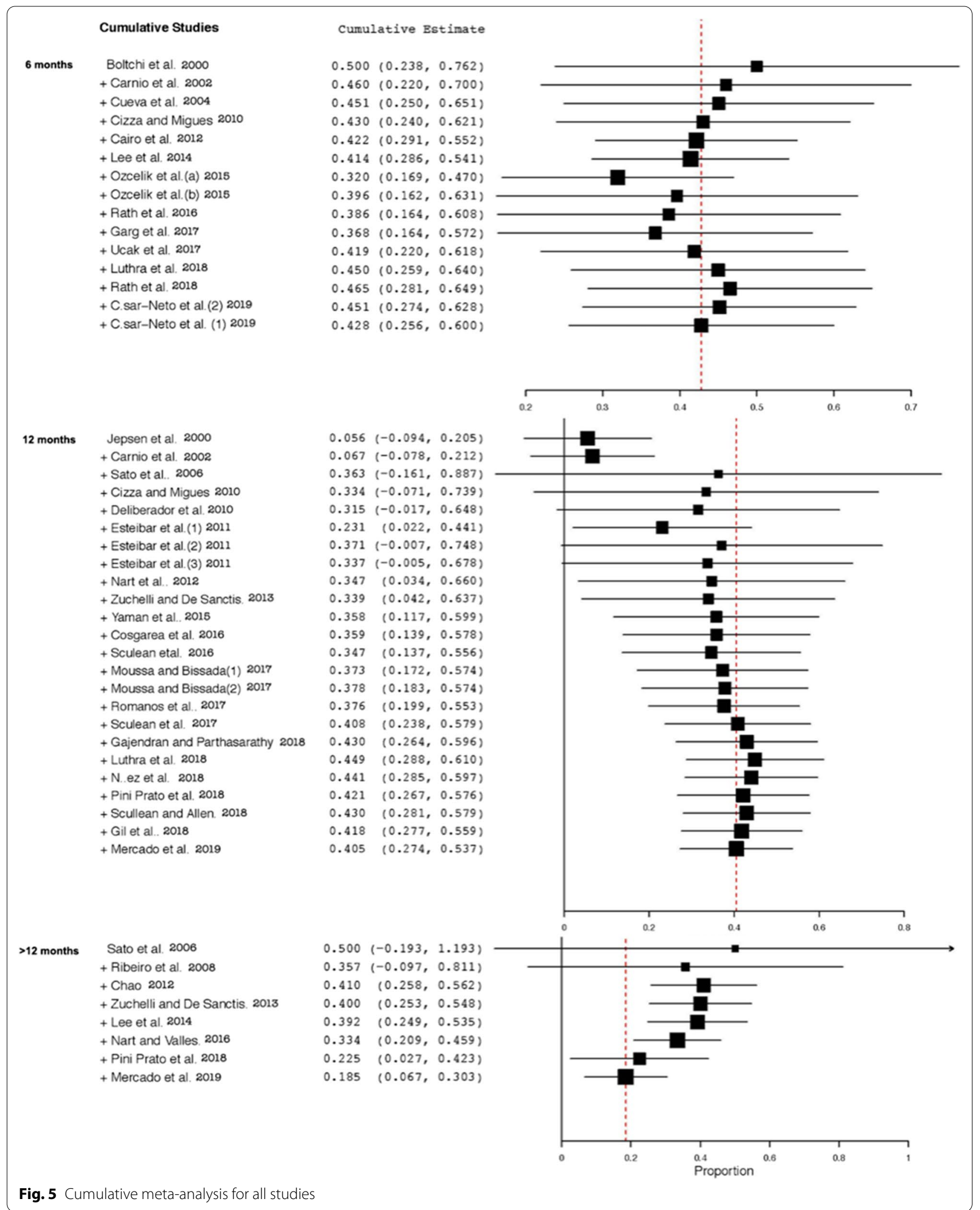


in recessions in which, until now, only a partial coverage could be achieved. Considering the characteristics of the recessions, in the consensus report of the 10th European Workshop on Periodontology, it was stated that interproximal attachment loss would not necessarily be a prognostic limitation to obtain a successful root coverage $[4,76]$. As a matter of fact, a similar behavior has been observed in GRs with no interproximal attachment loss and in those with a loss of interproximal attachment $\leq 3 \mathrm{~mm}$ [7]. Hence, this should not be the only parameter to consider when trying to predict successful coverage [8].

On the other hand, there would also be patient-related factors, such as bad oral hygiene, poor general health or smoking, which have been associated with negative results when performing any periodontal surgery [54, 77]. Therefore, the same might be expected for mucogingival surgery, but to our knowledge, there is no clinical study that has assessed the influence of delayed healing associated with certain determined systemic diseases on root coverage. In fact, the majority of patients in these studies usually showed good oral hygiene and general health, and were non-smokers, so these results should initially be extrapolated only to this kind of patients. Furthermore, while the analysis at the patient level may be more clinically relevant as it might allow assessing the results on each surgery [6], it would also be interesting to analyze results at recession level in order to know the amount of coverage can be achieved with each technique and to enable comparison between studies.

In this review, we have focused on surgical techniques, in which many variables might also influence a successful coverage, such as flap tension [78], position of the gingival margin coronally to the CEJ after suturing [79], root surface treatment [80], the surgeon's skills with root coverage improving along with surgical experience $[81,82]$, which would also be reflected in the so-called "center effect" [76, 83], the type of graft, and finally, the thickness of the subepithelial connective tissue graft. Although connective tissue graft is still considered as the gold standard [8], multiple materials are being developed in an attempt to avoid a second surgical site while achieving the same results. Concerning thickness of the autogenous graft, some authors advocated a graft thicker than $2 \mathrm{~mm}[50,67]$ for better results of CRC. On the other hand, other authors suggested that the thicker the graft, the greater the difficulties it will have for its vascularization and the worse the aesthetic results will be [84].

When the cumulative meta-analysis was performed, better results of CRC were observed in the more recent studies with a 12-month follow-up, regardless of the technique used. However, the opposite was seen when the follow-up was longer than 12 months. Improved knowledge, materials and techniques, such as microsurgery [85] may provide better results in achieving CRC in the short term, but it seems that the ageing of tissues, in particular changes in the thickness of the periodontium, could generate a biological remodeling due to long-term environmental influence [51], unlike what would be expected at around 12 months because of the "creeping attachment" [86] of the periodontal tissues. The difficulty lies in knowing at what point this initial maturation, which favors root coverage, begins to age and to be detrimental to the results obtained.

In terms of the limitations of the present review, the scarce evidence available for the treatment of Class III [4] or RT2 [5] GRs should be highlighted, as opposed to the existing evidence for Class I/II [4] or RT1 [5] recessions. In addition, the vast majority of the studies were case reports or case series, so the results should be viewed with caution since there was a high risk of bias, in many cases due to the lack of a masked operator and a blind examiner. It should also be considered that with the available measuring instruments, only linear measurements could be carried out, especially when trying to assess the extent of the avascular area of a recession. Thus, advances in digital [69] and three-dimensional techniques could suppose a great benefit.

Also, most of the studies had a short follow-up, which was insufficient to elucidate what will happen with CRC in the long-term. Matter [86] postulated that "creeping attachment" might happen up to one year after the surgical intervention, which would improve the clinical results in gingival recessions. As this has been extrapolated to all mucogingival techniques when treating any type of recession, including Miller class III [4] or RT2 [5] GRs, the percentage of CRC registered after a year $(42.07 \%)$ should not be lower than that obtained at six months (54.88\%), in contrast to what was noted in this review. Matter [86] pointed that the stability of the coverage was maintained after five years of followup. Instead, Pini-Prato et al. [51], stated that in Miller class III [4] or RT2 [5] GRs the stability of the CRC was not possible after a follow-up of 20 years. It has been suggested that different factors, such as the presence of an attached keratinized tissue band smaller than $2 \mathrm{~mm}$, the absence of interdental periodontal tissue or ageing, might be responsible for this fact [51]. Therefore, longer follow-ups in the same type of recessions, assessing the healing and stability of the tissues in the long term, could help to clarify this critical issue to clinicians, together with collecting more clinical variables, that, as it has been observed, could influence the results of root coverage.

Although the surgical technique and the type of recession influence the results of CRC, there are 
multiple other variables that are known to condition this outcome and that need to be investigated independently in order to know their correlation with CRC, such as the periodontal phenotype, absence of keratinized gingiva, tooth location, dimension and position (tooth extrusion, rotation or vestibular displacement) and the presence of frenula or shallow vestibular depth.

\section{Conclusions}

Within the limits of this review, it can be stated that it might be possible to achieve CRC, regardless of which technique is used, but its stability is not predictable. Nevertheless, there are many low-quality studies for the treatment of Miller class III or RT2 recessions, with short follow-up times. Hence, more randomized clinical trials are needed, with longer follow-ups and with several visits to assess the outcomes of the root coverage and the effectiveness of the surgical procedures, in order to develop more predictable techniques and to confirm the stability of the results achieved in Miller class III or RT2 recessions. Moreover, studies assessing the patient's satisfaction in relation with the clinical outcomes (mean root coverage, the state of the surrounding tissues), might be necessary in order to establish success criteria in the treatment of these recessions.

\begin{abstract}
Abbreviations
GRs: Gingival recessions; RC: Root coverage; CRC: Complete root coverage; PRISMA: Preferred Reporting Items for Systematic Review and Meta-Analysis; PROSPERO: International Prospective Register of Ongoing Systematic Reviews; GRADE: Grading of Recommendations. Assessment, Development and Evaluation; AF1: Additional File 1; TT: Tunnel technique; MCAT: Modified coronally advanced tunnel; VISTA: Vestibular incision subperiosteal tunnel access; CAF: Coronally advanced flap; PST: Pinhole surgical technique; LCT: Laterally closed tunnel; BFP: Bridge flap procedure; FGG: Free gingival graft; PCTG: Periosteal connective tissue grafting; MCAF: Modified coronally advanced flap; GUT: Gingival unit transfer; ROT: Rotated Technique; DPG: Double pedicle graft; LMCAF: Laterally moved coronally advanced flap; MLPF: Modified laterally positioned flap; LPF: Laterally positioned flap; 2SSA: Two-Step Surgical Approach; AERSA: Avascular root surface areas; CEJ: Cementum enamel junction; S: Single; RC: Recession; M: Multiple; Mx: Maxilla; Md: Mandible; NR: No reported; ADM: Acelullar dermal matrix; XCM: Xenogenic collagen matrix; SCTG: Subepithelial connective tissue graft; BB: Bioabsorbable barrier; EMD: Enamel matrix derivative; PRF: Platelet-rich fibrin; PDGF: Platelet derived growth factor; Mo: Months; PD: Probing depth; CAL: Clinical attachment level; KTW: Keratinized tissue width.
\end{abstract}

\section{Supplementary Information}

The online version contains supplementary material available at https://doi. org/10.1186/s12903-021-01494-3.

Additional file 1. Excluded studies and reasons for their exclusion. The additional file 1 shows a table including all the excluded studies and the reasons of their exclusion. All the references of these excluded studies are inside the additional file 1.

Acknowledgements

Not applicable.
Authors' contributions

AFJ, AMGF and REF contributed equally to this work. AFJ and LAAZ designed the study. AFJ and AMGF contributed to Project Administration. AFJ, AMGF, REF and XMM contributed to the data collection and data analysis/interpretation. AFJ, AMGF, REF and LAAZ have drafted the work and revised the manuscript draft. JMAU: contributed to critical revision of the article. All the authors read and approved the final manuscript.

\section{Funding}

This research was not supported by any specific funding agency in the public, commercial, or not-for-profit sectors; and authors report no conflicts of interest related to this manuscript. We declare that AFJ, JMAU and XMM have previously received grants from the University of the Basque Country (UPV/ EHU) (PPG17/01).

\section{Availability of data and materials}

All data generated or analysed during this study are included in this published article [and its supplementary information files].

\section{Declarations}

Ethics approval and consent to participate

Not applicable for that section.

Consent for publication

Not applicable for that section.

\section{Competing interests}

The authors declare that they have no competing interests.

\section{Author details}

'Department of Stomatology II, University of the Basque Country (UPV/ EHU), UPV/EHU. Barrio Sarriena S/N, 48940 Leioa, Biscay, Spain. ${ }^{2}$ Department of Nursing I, University of the Basque Country (UPV/EHU), Barrio Sarriena S/N, 48940 Leioa, Biscay, Spain.

Received: 5 November 2020 Accepted: 7 March 2021

Published online: 22 March 2021

\section{References}

1. Chapple IL, Van der Weijden F, Doerfer C, et al. Primary prevention of periodontitis: managing gingivitis. J Clin Periodontol. 2015;42(Suppl 16):S71-76.

2. Chapple IL. Time to take periodontitis seriously. BMJ. 2014;348:92645.

3. Petersen PE, Ogawa $\mathrm{H}$. The global burden of periodontal disease: towards integration with chronic disease prevention and control. Periodontol. 2000;2012(60):15-39.

4. Miller PD. A classification of marginal tissue recession. Int J Periodontics Restorative Dent. 1985:5:8-13

5. Cairo F, Nieri M, Cincinelli S, Mervelt J, Pagliaro U. The interproximal clinical attachment level to classify gingival recessions and predict root coverage outcomes: an explorative and reliability study. J Clin Periodontol. 2011:38:661-6.

6. Aroca S, Keglevich T, Nikolidakis D, et al. Treatment of class III multiple gingival recessions: a randomized-clinical trial. J Clin Periodontol. 2010;37:88-97.

7. Cairo F, Cortellini P, Tonetti M, et al. Coronally advanced flap with and without connective tissue graft for the treatment of single maxillary gingival recession with loss of inter-dental attachment. A randomized controlled clinical trial. J Clin Periodontol. 2012;39:760-8.

8. Cortellini P, Bissada NF. Mucogingival conditions in the natural dentition: Narrative review, case definitions, and diagnostic considerations. J Clin Periodontol. 2018;45(Suppl 20):S190-198.

9. Jepsen S, Caton JG, Albandar JM, et al. Periodontal manifestations of systemic diseases and developmental and acquired conditions: consensus report of workgroup 3 of the 2017 World Workshop on the Classification of Periodontal and Peri-Implant Diseases and Conditions. J Periodontol. 2018;89(Suppl 1):S237-248. 
10. Maloney WJ, Weinberg MA. Implementation of the American Society of Anesthesiologists Physical Status classification system in periodontal practice. J Periodontol. 2008;79:1124-6.

11. Rotundo R, Nieri M, Mori M, Clauser C, Prato GP. Aesthetic perception after root coverage procedure. J Clin Periodontol. 2008;35:705-12.

12. Greenwell H, Bissada NF, Henderson RD, Dodge JR. The deceptive nature of root coverage results. J Periodontol. 2000;71:1327-37.

13. Moher D, Liberati A, Tetzlaff J, Altman DG, Group P. Preferred reporting items for systematic reviews and meta-analyses: the PRISMA statement. PLoS Med. 2009;6:e1000097.

14. Cueva MA, Boltchi FE, Hallmon WW, Nunn ME, Rivera- Hidalgo F, Rees T. A comparative study of coronally advanced flaps with and without the addition of enamel matrix derivative in the treatment of marginal tissue recession. J Periodontol. 2004;75:949-56.

15. Jepsen K, Stefanini M, Sanz M, Zucchelli G, Jepsen S. Long-term stability of root coverage by coronally advanced flap procedures. J Periodontol. 2017;88:626-33.

16. Atkins D, Eccles M, Flottorp $S$, et al. Systems for grading the quality of evidence and the strength of recommendations I: critical appraisal of existing approaches The GRADE Working Group. BMC Health Serv Res. 2004:4:38.

17. Grupe HE, Warren RF. Repair of gingival defects by an sliding flap operation. J Periodontol. 1956;27:92-5.

18. Bernimoulin JP, Lüscher B, Mühlemann HR. Coronally repositioned periodontal flap. Clinical evaluation after one year. J Clin Periodontol. 1975;2:1-13.

19. HolbrookT, Ochsenbein C. Complete coverage of the denuded root surface with a one-stage gingival graft. Int J Periodontics Restorative Dent. 1983;3:8-27.

20. Langer B, Langer L. Subepithelial connective tissue graft technique for root coverage. J Periodontol. 1985:56:715-20.

21. Marggraf E. A direct technique with a double lateral bridging flap for coverage of denuded root surface and gingiva extension. Clinical evaluation after 2 years. J Clin Periodontol. 1985;12:69-76.

22. Nelson SW. The subpedicle connective tissue graft. A bilaminar reconstructive procedure for the coverage of denuded root surfaces. J Periodontol. 1987;58:95-102.

23. Allen EP. Use of mucogingival surgical procedures to enhance esthetics. Dent Clin North Am. 1988;32:307-30.

24. Allen EP, Miller PD. Coronal positioning of existing gingiva: short term results in the treatment of shallow marginal tissue recession. J Periodontol. 1989:60:316-9.

25. Harris RJ. The connective tissue and partial thickness double pedicle graft: a predictable method of obtaining root coverage. J Periodontol. 1992;63:477-86.

26. Ito K, Owa M. Connective tissue grafting for root coverage in multiple Class III gingival recessions with enamel matrix derivative: a case report. Pract Periodontics Aesthet Dent. 2000;12:441-6; quiz 448

27. Zucchelli G, De Sanctis M. Treatment of multiple recession-type defects in patients with esthetic demands. J Periodontol. 2000;71:1506-14.

28. Allen AL, Cohen DW. King and Pennel's free graft series: a defining moment revisited. Compend Contin Educ Dent. 2003;24:698-700, 702, 704-706.

29. Tözüm TF, Dini FM. Treatment of adjacent gingival recessions with subepithelial connective tissue grafts and the modified tunnel technique. Quintessence Int. 2003;34:7-13.

30. Zucchelli G, Cesari C, Amore C, Montebugnoli L, De Sanctis M. Laterally moved, coronally advanced flap: a modified surgical approach for isolated recession-type defects. J Periodontol. 2004;75:1734-41.

31. Ribeiro FS, Zandim DL, Pontes AEF, Mantovani RV, Sampaio JEC, Marcantonio E Jr. Tunnel technique with a surgical maneuver to increase the graft extension: case report with a 3-year follow-up. J Periodontol. 2008;79:753-8.

32. Chambrone LA, Chambrone L. Treatment of Miller Class I and II localized recession defects using laterally positioned flaps: a 24-month study. Am J Dent. 2009:22:339-44.

33. Zucchelli G, Mele M, Mazzotti C, Marzadori M, Montebugnoli L, De Sanctis M. Coronally advanced flap with and without vertical releasing incisions for the treatment of multiple gingival recessions: a comparative controlled randomized clinical trial. J Periodontol. 2009;80:1083-94.
34. Allen EP. Subpapillary continuous sling suturing method for soft tissue grafting with the tunneling technique. Int J Periodontics Restorative Dent. 2010:30:479-85.

35. Deliberador TM, Santos FR, Bosco AF, et al. Simultaneous application of combination of three surgical techniques for treatment of gingival recession: a case report. Bull Tokyo Dent Coll. 2010;51:201-5.

36. Chao JC. A Novel Approach to Root Coverage: The Pinhole Surgical Technique. Int J Periodontics Restorative Dent. 2012;32:521-31.

37. Zadeh $\mathrm{HH}$. Minimally invasive treatment of maxillary anterior gingival recession defects by vestibular incision subperiosteal tunnel access and platelet-derived growth factor BB. Int J Periodontics Restorative Dent. 2011;31:653-60.

38. Zucchelli G, De Sanctis M. Modified two-stage procedures for the treatment of gingival recession. Eur J Esthet Dent. 2013:8:24-42.

39. Lee CT, Chang PC, Touchan N, Royzman D. Root coverage with a modified laterally positioned flap combined with a subepithelial connective tissue graft in advanced recession. J Periodontal Implant Sci. 2014;44:300-6.

40. Nunez J, Sanz-Esporrin J, Caffesse R, Sanz M. A two-step surgical approach with flattening of the root surface to treat localized gingival recessions affecting mandibular incisors: a case series report. Int J Periodontics Restorative Dent. 2018;38:683-90.

41. Sculean A, Allen EP. The laterally closed tunnel for the treatment of deep isolated mandibular recessions: surgical technique and a report of 24 cases. Int J Periodontics Restorative Dent. 2018;38:479-87.

42. Mercado F, Hamlet S, Ivanovski S. Subepithelial connective tissue graft with or without enamel matrix derivative for the treatment of multiple Class III-IV recessions in lower anterior teeth: A 3-year randomized clinical trial. J Periodontol. 2020;91:473-83.

43. Boltchi FE, Allen EP, Hallmon WW. The use of a bioabsorbable barrier for regenerative management of marginal tissue recession. I. Report of 100 consecutively treated teeth. J Periodontol. 2000;71:1641-53.

44. Carnio J, Camargo PM, Kenney EB, Schenk RK. Histological evaluation of 4 cases of root coverage following a connective tissue graft combined with an enamel matrix derivative preparation. J Periodontol. 2002;73:1534-43.

45. Cosgarea R, Juncar R, Arweiler N, Lascu L, Sculean A. Clinical evaluation of a porcine acellular dermal matrix for the treatment of multiple adjacent class I, II, and III gingival recessions using the modified coronally advanced tunnel technique. Quintessence Int. 2016:47:739-47.

46. Garg S, Arora SA, Chhina S, Singh P. Multiple gingival recession coverage treated with vestibular incision subperiosteal tunnel access approach with or without platelet-rich fibrin-A case series. Contemp Clin Dent. 2017:8:464-8.

47. Gupta V, Bains VK, Mohan R, Bains R. Bridge flap technique as a singlestep solution to mucogingival problems: a case series. Contemp Clin Dent. 2011;2:110-4

48. Jepsen S, Heinz B, Kermanie MA, Jepsen K. Evaluation of a new bioabsorbable barrier for recession therapy: a feasibility study. J Periodontol. 2000;71:1433-40.

49. Nart J, Valles C, Mareque S, Santos A, Sanz-Moliner J, Pascual A. Subepithelial connective tissue graft in combination with a coronally advanced flap for the treatment of Miller Class II and III gingival recessions in mandibular incisors: a case series. Int J Periodontics Restorative Dent. 2012:32:647-54.

50. Nart J, Valles C. Subepithelial Connective Tissue Graft in Combination with a Tunnel Technique for the Treatment of Miller Class II and III Gingival Recessions in Mandibular Incisors: Clinical and Esthetic Results. Int J Periodontics Restorative Dent. 2016;36:591-8.

51. Pini Prato GP, Magnani C, Chambrone L. Long-term evaluation (20 years) of the outcomes of coronally advanced flap in the treatment of single recession-type defects. J Periodontol. 2018;89:265-74.

52. Romanos AH, Abou-Arraj RV, Cruz SE, Majzoub ZA. Clinical and patientcentered outcomes following treatment of multiple gingival recessions using acellular dermal matrix allografts. Int J Periodontics Restorative Dent. 2017:37:843-51.

53. Sato S, Yamada K, Kato T, Haryu K, Ito K. Treatment of Miller Class III recessions with enamel matrix derivative (Emdogain) in combination with subepithelial connective tissue grafting. Int J Periodontics Restorative Dent. 2006;26:71-7.

54. Sculean A, Cosgarea R, Stähli A, et al. Treatment of multiple adjacent maxillary Miller Class I, II, and III gingival recessions with the modified coronally advanced tunnel, enamel matrix derivative, and 
subepithelial connective tissue graft: a report of 12 cases. Quintessence Int. 2016;47:653-9.

55. Sculean A, Cosgarea R, Katsaros C, Arweiler NB, Miron RJ, Deppe H. Treatment of single and multiple Miller Class I and III gingival recessions at crown-restored teeth in maxillary esthetic areas. Quintessence Int. 2017;48:777-82.

56. Yaman D, Demirel K, Aksu S, Basegmez C. Treatment of multiple adjacent miller class III gingival recessions with a modified tunnel technique: a case series. Int J Periodontics Restorative Dent. 2015:35:489-97.

57. Cizza N, Migues D. Progressive root resorption associated with the treatment of deep gingival recession. A clinical case. Int J Periodontics Restorative Dent. 2010;30:619-25.

58. Gajendran P, Parthasarathy H. Management of Miller's class III recession defect with gingival unit transfer-a promising technique. J Clin Diagn Res. 2017;12:ZD14-6.

59. Luthra S, Grover HS, Yadav A, Masamatti S. Ascertaining the regenerative potential of the "gold standard" grafts: Achieving 100\% root coverage in Miller's Class III recession with periosteal pedicle graft and autogenous bone. J Indian Soc Periodontol. 2018;22:277-81.

60. Moussa EW, Bissada NF. Comparative outcomes of miller class iii gingival recession treatment using the tunnel or coronally advanced flap approach: a case report. Clin Adv Periodontics. 2017;7:35-41.

61. Rath A, Varma S, Paul R. Two-stage mucogingival surgery with free gingival autograft and biomend membrane and coronally advanced flap in treatment of class III Millers recession. Case Rep Dent. 2016;2016:9289634.

62. Rath A, Fernandes BA, Ramamurthy PH, Sidhu P, Saichandran S. Root coverage of class III recession using free gingival graft using novel root coverage esthetic score. J Clin Diagn Res. 2018;12:ZD01-3.

63. Ozcelik O, Seydaoglu G, Haytac MC. An explorative study to develop a predictive model based on avascular exposed root surface area for root coverage after a laterally positioned flap. J Periodontol. 2015;86:356-66.

64. Ucak O, Ozcan M, Seydaoglu G, Haytac MC. Microsurgical instruments in laterally moved, coronally advanced flap for Miller class III isolated recession defects: a randomized controlled clinical trial. Int J Periodontics Restorative Dent. 2017;37:109-15.

65. Ozcelik O, Seydaoglu G, Haytac MC. Prediction of root coverage for single recessions in anterior teeth: a 6-month study. J Clin Periodontol. 2015:42:860-7.

66. Cesar Neto JB, Cavalcanti MC, Sekiguchi RT, Pannuti CM, Romito GA, Tatakis DN. Root coverage for single deep gingival recessions: outcomes based on a decision-making algorithm. Int J Dent. 2019;2019:1830765.

67. Esteibar JR, Zorzano LA, Cundín EE, Blanco JD, Medina JR. Complete root coverage of Miller class III recessions. Int J Periodontics Restorative Dent. 2011:31:e1-7.

68. Gil A, Bakhshalian N, Min S, Zadeh HH. Treatment of multiple recession defects with vestibular incision subperiosteal tunnel access (VISTA): a retrospective pilot study utilizing digital analysis. J Esthet Restor Dent. 2018;30:572-9.

69. Saletta D, Pini Prato G, Pagliaro U, Baldi C, Mauri M, Nieri M. Coronally advanced flap procedure: is the interdental papilla a prognostic factor for root coverage? J Periodontol. 2001;72:760-6.

70. Berlucchi I, Francetti L, Del Fabbro M, Basso M, Weinstein RL. The influence of anatomical features on the outcome of gingival recessions treated with coronally advanced flap and enamel matrix derivative: a 1-year prospective study. J Periodontol. 2005;76:899-907.
71. Bouchard P, Malet J, Borghetti A. Decision-making in aesthetics: root coverage revisited. Periodontol. 2000;2001 (27):97-120.

72. Hwang D, Wang HL. Flap thickness as a predictor of root coverage: a systematic review. J Periodontol. 2006;77:1625-34.

73. Fischer KR, Alaa K, Schlagenhauf U, Fick I. Root coverage with a modified lateral sliding flap—a case series. Eur J Esthet Dent. 2012;7:120-8.

74. Müller HP, Stahl M, Eger T. Failure of root coverage of shallow gingival recessions employing GTR and a bioresorbable membrane. Int J Periodontics Restorative Dent. 2001;21:171-81.

75. Chambrone LA, Chambrone L. Subepithelial connective tissue grafts in the treatment of multiple recession-type defects. J Periodontol. 2006;77:909-16.

76. Tonetti MS, Jepsen S, Periodontology W, Got E, Wo. Clinical efficacy of periodontal plastic surgery procedures: consensus report of Group 2 of the 10th European Workshop on Periodontology. J Clin Periodontol. 2014:41(Suppl 15):S36-S43.

77. Chambrone L, Tatakis DN. Periodontal soft tissue root coverage procedures: a systematic review from the AAP Regeneration Workshop. I Periodontol. 2015;86(2 Suppl):S8-51.

78. Pini Prato G, Pagliaro U, Baldi C, et al. Coronally advanced flap procedure for root coverage. Flap with tension versus flap without tension: a randomized controlled clinical study. J Periodontol. 2000;71:188-201.

79. Pini Prato GP, Baldi C, Nieri M, et al. Coronally advanced flap: the postsurgical position of the gingival margin is an important factor for achieving complete root coverage. J Periodontol. 2005;76:713-22.

80. Santamaria MP, da Silva FD, Nociti FH, Casati MZ, Sallum AW, Sallum EA. Cervical restoration and the amount of soft tissue coverage achieved by coronally advanced flap: a 2-year follow-up randomized-controlled clinical trial. J Clin Periodontol. 2009;36:434-41.

81. Barker TS, Cueva MA, Rivera-Hidalgo F, et al. A comparative study of root coverage using two different acellular dermal matrix products. J Periodontol. 2010;81:1596-603

82. Miller PD. Root coverage using the free soft tissue autograft following citric acid application. III. A successful and predictable procedure in areas of deep-wide recession. Int J Periodontics Restorative Dent. 1985;5:14-37.

83. Pini-Prato G. The Miller classification of gingival recession: limits and drawbacks. J Clin Periodontol. 2011;38:243-5.

84. Zucchelli G, Amore C, Sforza NM, Montebugnoli L, De Sanctis M. Bilaminar techniques for the treatment of recession-type defects. A comparative clinical study. J Clin Periodontol. 2003;30:862-70.

85. Burkhardt R, Lang NP. Coverage of localized gingival recessions: comparison of micro- and macrosurgical techniques. J Clin Periodontol. 2005;32:287-93.

86. Matter J. Creeping attachment of free gingival grafts. A five-year followup study. J Periodontol. 1980;51:681-5.

\section{Publisher's Note}

Springer Nature remains neutral with regard to jurisdictional claims in published maps and institutional affiliations.

\footnotetext{
Ready to submit your research? Choose BMC and benefit from:

- fast, convenient online submission

- thorough peer review by experienced researchers in your field

- rapid publication on acceptance

- support for research data, including large and complex data types

- gold Open Access which fosters wider collaboration and increased citations

- maximum visibility for your research: over 100M website views per year
}

At BMC, research is always in progress.

Learn more biomedcentral.com/submissions 